\title{
PROJECT DAFFODIL
}

\section{Hothouse flowers.}

\section{BY SYLVIA SPRUCK WRIGLEY}

$\mathrm{T}$ he Daffodil Project is a joint venture between the United Nations, ESA and Friends of the Elderly. I am their 17th civilian recruit. For obvious reasons, the entire project is extremely hush-hush.

My daughter hates the Project.

"Maman," she said. Amélie visits once a week. "Maman, let me take you out of here. There's no mission." I thought we'd had our funding cut. Then I saw the look her son Daniel gave her. Poor Amélie. She doesn't think I should be considering space travel, not at my age. Every visit she's tried to tell me that the Daffodil Project doesn't exist. We've had this conversation so many times.

"What's the harm," Daniel whispered, like I can't hear. At least he understands I'm not abandoning them, or if I am, well ... funny, that my grandson would be the one to understand.

"Tell me again, grand-mère, how are they going to get all of you to Mars? Will you get a window seat? Can you send me pictures?"

Amélie scowled. She's always hid her fear under a face full of anger. She can't bear the thought of my leaving her, even though she knows it will happen someday. I wish I could comfort her like I did when she was a little girl scared of thunder. She'll be 50 in February but she's still my Mélie.

"I don't think the space-transport will have windows," I told Daniel. "It's not a pleasure cruise. But once we arrive, we'll be able to see Mars and get instructions from Earth. We have some sort of data transfer over satellite for systems monitoring. I bet we'll even have voice data. I'll have to ask Jacques..."

The nurse walking past smiled. "Aren't you the clever one, Madame."

That was when Amélie stormed out, threatening to shut the place down as she dragged her son out the door. I didn't mind. I could see Claudine setting up the card table for a game of belote.

These are my friends now. Paul spread chocolates on the card table, a gift from his granddaughter. Awful American chocolate, but we all took a piece anyway. We'll be on hard rations soon

\section{ONATURE.COM}

Follow Futures:

@ @NatureFutures

f go.nature.com/mtoodm enough. We're trying to emulate life on the space station so the food is not very good, all government approved. The thing is, when we get up there, there's no coming back. So if an addiction to croissants or cognac is going to break your heart, you'd better find out now.

Or if leaving for Mars is going to break your daughter's heart.

Claudine was dealer, as always. She's 83 , the eldest. She's also the best belote player, although Jacques swears she cheats.

There's two dozen of us here in the home, if I don't count Monsieur Coulon, which I don't because he's really just a bundle of robes and drool. I guess they keep him with us as a test, to see how we cope when someone loses it completely but doesn't die. The nurses said not everyone can go to space. So maybe they're sending a dozen, or less?

We're all very well behaved because we want to get chosen. It's true, Mars's surface is too cold for space colonies. But heating up a planet is not a problem; it just takes time. It's on the television every evening how we've overheated this one, after all. Jacques and I have worked out the super-secret plan: send a small team to Mars to oversee operations. Repeat as necessary until the planet is inhabitable and then invite the masses. Voilà: new homeland.

Amélie thinks I'm deluded. She half expects me to transfer my life's savings to a con-man or something. But honestly, my life's savings are $\mathrm{€} € 800$-per-month pension and the house that Antoine and I bought in 1972. Really, what do I have to lose?

What Amélie doesn't understand is that we aren't colonizing. We're Project Daffodil, the first inhabitants of chilly Mars. Jacques and I, we've worked it all out. They can't afford to keep ferrying people back and forth. But we've got some time left, five years, maybe ten. Our job is to keep an eye on things and wait to die.

If you want to save money with a one-way trip, it makes perfect sense to recruit from a nursing home, now doesn't it?

This is why we practise survival skills. We can't live on the surface, obviously, so we'll have a dome. It's going to be small and uncomfortable, like our shared rooms here: just enough space for two beds and a cupboard, no chance of privacy.

If it is just four of us, I hope I get to go with Claudine and Paul and Jacques. We play belote every afternoon and tell stories and have a grand time when we can convince one of the grandchildren to bring us pastis. I guess they won't give us pastis up there, but we'll take the cards. We'll get by.

Amélie keeps making up excuses to try to get me out of here. She's frantic for me to come and live with her now, leave the home and the Project.

I told her that I'll think about it, but Jacques thinks they are confirming the final crew soon. Maybe even tonight.

Since Antoine died, every morning I wake up and remember that I'm decrepit. That he abandoned me to live my old age alone. Every morning I remember that there's no future, my entire life is in the past. So, what do I do?

I could deaden it with pastis until someone carts me away.

Or I could go to Mars.

Tell Amélie that I will miss her.

Sylvia Spruck Wrigley was born in Germany and spent her childhood in Los Angeles. She now splits her time between South Wales and Andalucia. Her fiction was nominated for a Nebula in 2014 and her short stories have been translated into more than a dozen languages. Her first novella, Domnall and the Borrowed Child, is out now as part of the Tor.com novella imprint. You can find out more about her at www. intrigue.co.uk. 